\title{
Larra durante la ominosa década
}

JOSÉ ESCOBAR

Universidad de Toronto

Todavía no tenemos una biografía satisfactoria de Larra, la biografía que un escritor de su importancia requiere. Sin embargo, después de los importantes trabajos biográficos de A. Rumeau, F. C. Tarr e Ismael Sánchez Estevan, las recientes investigaciones de Gregorio C. Martín, Luis Lorenzo-Rivero, Jorge Urrutia y José Luis Varela nos acercan a esa biografía que echamos de menos. Las aportaciones documentales de estos investigadores ofrecen nuevos conocimientos sobre los años de formación del escritor que hay que tener en cuenta con respecto a esfuerzos anteriores para situar los orígenes de la obra de Larra, sobre todo sus dos primeras series de artículos, El Duende Satírico del Día y El Pobrecito Hablador, en una corriente ideológica nacional que, originada en espíritu de reforma propio de la Ilustración dieciochesca, conduce en el siglo XIX al liberalismo, pasando por dos perío- 
dos constitucionales anteriores a la restauración absolutista, en cuyo ambiente Larra empieza a escribir ${ }^{1}$.

En un artículo de 1977, «Larra, defensor de Fernando VII», Jorge Urrutia nos dio los primeros indicios de que Larra, «deseoso de enrolarse en los Voluntarios Realistas, cuerpo paramilitar partidario a ultranza del monarca absoluto, no fue siempre, por tanto, un hombre de la oposición ${ }^{2}$. En este artículo se reproduce una instancia de Larra, fechada el 29 de enero de 1827 , en la que el muchacho expone que no habiendo sido resuelta su solicitud anterior del mes de noviembre para alistarse en los Voluntarios Realistas, de nuevo reitera sus deseos de servir al Rey en dicho cuerpo armado. Tampoco fue admitido esta vez, seguramente por no haber cumplido todavía, en contra de lo que escribe en la instancia, la edad reglamentaria de dieciocho años.

Poco después, el profesor José Luis Varela proporciona nuevos datos en su trabajo "Larra, voluntario realista» ${ }^{3}$ : Con una nueva solicitud, sin fecha, es por fin admitido el 9 de marzo de 1827, dos semanas antes de cumplir los dieciocho años. Por este nuevo documento averiguamos que el muchacho había conseguido entre tanto un empleo en la Inspección de Voluntarios Realistas. Es, sin duda, el empleo de que hablan sus biógrafos desde Cayetano Cortés en 1842. J. L. Varela volvió a tratar el tema en otro artículo sobre la evolución ideológica del escritor y el significado que en ella tienen las Palabras de un creyente, de Félicité de Lamennais ${ }^{4}$. Ahora, estos artículos los ha reunido el autor con otros en su reciente libro Larra y España ${ }^{5}$, donde adquieren una unidad basada en la presentación de una nueva imagen de la personalidad del escritor como respuesta a la controversia ideológica que ha ocupado a la crítica desde el momento del suicidio.

¿Cómo interpretar estos nuevos documentos aportados por Jorge Urrutia y J. L. Varela? El primero cree que a pesar de que Larra deseara reiteradamente «ingresar en un cuerpo defensor del absolutismo y la

1 Véase J. Escobar, «Un soneto político de Larra», BHi, LXXI, 1969, pp. 280-285; «El pobrecito hablador, de Larra y su intención satírica», $P S A, 1972$, pp. 5-44, y Los orígenes de la obra de Larra, Madrid, Prensa Española, 1973.

2 Insula, núm. 366, mayo de 1977, p. 3.

3 «Larra, voluntario realista (Sobre un documento inédito y su circunstancia)», $H R$, XLVI, 1978, pp. 407-420.

4 «Lamennais en la evolución ideológica de Larra», HR, XLVIII, 1980, pp. 287306.

5 Madrid, Espasa-Calpe, 1983. Cito los textos de J. L. Varela por esta edición, indicando las páginas entre paréntesis después de la cita. 
reacción [...] probablemente no [poseia] un pensamiento político muy definido, aunque se lo podemos suponer de tendencia liberal» (loc. cit.). En cambio, el profesor Varela excluye completamente el liberalismo de la ideología originaria del escritor, situándola dentro del espectro político del realismo, de acuerdo con sus compromisos biográficos con el régimen absolutista y con los elogios al Rey, paternalmente inclinado a buscar «una salida relativamente satisfactoria a los deseos de unos y otros» (p. 242). El autor de Larra y España previene contra «posibles manipulaciones, partidistas, interesadas quizás en hacer de este documento una denuncia de absolutismo contra uno de los campeones, pocos años después, de la oposición liberal desde la prensa» (p. 144). Del mismo modo advierte contra «ciertos desvelos exegéticos para localizar en la obra de esta época resquicios críticos, oposición solapada, anticipos, en una palabra, del adalid del liberalismo que viene después» (p. 28). El autor llega a la conclusión un tanto sorprendente de que alistarse en 1827 en las fuerzas paramilitares del régimen equivale a suscribir una opción política moderada (p. 242). Según esta interpretación, el joven Larra no sería ni apostólico ni liberal, sino un «realista moderado» que expresa su amor y admiración al Rey absoluto con elogios tales como «Rey justo» (lo de «hombre grande» va dirigido a Cervantes, no al rey, p. 28), «excelso Monarca», «Monarca ilustrado», «Rey de Paz» y no sé cuántas cosas más (pp. 28-29). Aunque haya que reconocer que en los últimos meses de la ominosa década Larra expresa «una nítida insatisfacción primera (el subrayado es mío) ante lo instituido y recibido» (p. 29), a la muerte del Rey, empujado por las circunstancias, realiza en 1834 «una apresurada conversión liberal» (p. 187). Pero al final, «el liberalismo moderado y conservador renace cuando el hombre interior muere» (p. 41). De acuerdo con esta interpretación, la ideología moderada y conservadora renace de sus raíces realistas.

Pero ¿quiénes eran estos «realistas moderados» a cuya ideología habría que adscribir el conservadurismo originario de Larra? El término, como indica Julio Aróstegui, se presta a gran confusión ${ }^{6}$. Ahora bien, si tomamos a los que podríamos llamar «realistas moderados puros», como el ministro de Hacienda Luis López Ballesteros y sus colaboradores Sebastián de Miñano, Alberto Lista, Reinoso, Gómez Hermosilla, Javier de Burgos, tendremos que ver en ellos a los afrancesados partidarios de la monarquía absoluta que ante la situación económica y social del país intentan paliar la crisis financiera en que se halla

6 «El manifiesto de la "Federación de Realistas Puros" (1826). Contribución al estudio de los grupos políticos en el reinado de Fernando VII», Estudios de Historia Contemporánea, I, 1976, p. 126. 
el régimen y en lo político tratan de contrarrestar con ciertas reformas administrativas las presiones constitucionalistas. Para J. Aróstegui es «un grupo de tímidos reformistas colaboradores del Rey [...] dispuestos a mantener un absolutismo templado ${ }^{7}$, y según Miguel Artola constituyen la "fracción moderada del absolutismo» ${ }^{8}$. Su reformismo es, por lo tanto, absolutista. Hay que insistir en esto porque J. L. Varela considera, con razón, que sería un "yerro escandaloso» (p. 242) acusar a Larra de absolutismo. Sin embargo, si aceptamos que Larra fue realista, por muy moderado que fuera, de hecho estamos acusándolo - sin escándalo y con mesura - de absolutismo. Para exculparlo de una tacha semejante habrá que interpretar los hechos de otro modo.

Los biógrafos de Larra cuando tratan de aquellos años de iniciación acuden siempre al testimonio autobiográfico de la carta dirigida a sus padres desde Londres en 1835, en la que señala el año 1826 como punto de partida de su trayectoria vital. Es una declaración estremecedora, referida a un muchacho de diecisiete años: «y como estoy viviendo de milagro desde el año 26, me he acostumbrado a mirar el día de hoy como el último». Y añade: «usted dirá que vuelvo a mis ideas juveniles; yo no sé si algún día pensaré de un modo más alegre; pero aunque esto empezara a suceder mañana, siempre resultaría que había pasado rabiando una tercera parte lo menos de la vida; todavía quedaría por averiguar cuál de las tres es la más importante. No vayan ustedes a inferir de aquí que estoy de mal humor; no tengo por qué estarlo en el momento; pero hasta hora no he visto nunca delante de mí un horizonte bueno, y ahora empiezo a verlo malo si triunfa D. Carlos» ${ }^{9}$. Este recuerdo de sus «ideas juveniles» no nos hace pensar en el entusiasmo del joven Voluntario. En el oscuro horizonte juvenil evocado en esta carta hay que situar la interrupción de sus estudios, el empleo burocrático en la administración calomardina, la instancia para solicitar un empleo para su padre ${ }^{10}$, y también su insistencia en ser admitido en los Voluntarios Realistas. Larra, en efecto, parece que empieza a vivir de milagro.

7 Ibid., p. 181. Según este autor: «El moderantismo era más una solución que un partido. Sus hombres representativos son pocos, por mucha que fuera su significación en la política fernandina y, por ello, no es adecuado, tal vez, hablar de un partido moderado y menos de una masa moderada entre las familias del tiempo.» Ibid., p. 178, Los subrayados son del original.

8 La España de Fernando VII, Madrid, Espasa-Calpe, 1968, p. 853.

9 Obras de D. Mariano José de Larra (Fígaro), ed. de Carlos Seco Serrano, Madrid, B. A. E., 1960, IV, p. 273.

10 Véase Gregorio C. Martín, Hacia una revisión crítica de la biografía de Larra (Nuevos documentos), Porto Alegre, P. U. C., 1975, pp. 39-41, y Luis LorenzoRivero, «Larra. Fantasía y realidad», BRAE, LIV, 1974, pp. 203-219. 
Ya sabemos cuál es la interpretación política que hace J. L. Varela de la militancia de Larra en las filas de los Voluntarios Realistas, interpretación que ya he dicho antes me parece sorprendente. En efecto, según indica F. Suárez Verdaguer en una cita aducida por el propio Varela (p. 244), estos individuos fueron «a los ojos del pueblo - y casi podría afirmarse que especialmente a los ojos de los liberales - una fuerza armada incondicionalmente afecta al Rey y el más sólido apoyo del orden que representan, en fórmula de la época, el Altar y el Trono». Esto explicaría el sarcasmo de una noticia sobre la aparición de El Duende Satírico que Anthony Percival y yo hemos encontrado en una revista londinense de la época, la Foreign Review, en la que colaboraban asiduamente liberales españoles exiliados ${ }^{11}$. Con despectiva ironía, el corresponsal anónimo atribuye El Duende a un "entusiasta capitán de Voluntarios Realistas»:

The list of periodicals in the capital has just received an addition, under the title of Duende satírico del día. It is the product of a zealous captain of royalist Volunteers, from which, and from the further circumstance that the author's name, and that of the printer himself are hardly known, we may form a pretty fair idea of how profound and vivacious must be the satires of this Duendecillo ${ }^{12}$.

Por lo visto, la información sobre el autor de El Duende procedería de los rumores que correrían por los corrillos de Madrid donde Larra era todavía apenas conocido, con una exageración que lo asciende a capitán. En todo caso, para los que no lo conocieran, el hecho de ser Voluntario Realista tenía que hacerlo sospechoso de absolutismo calomardino y radical. A los ojos del pueblo era un ferviente defensor del Altar y el Trono.

Nada indica que los Voluntarios Realistas fueran un dechado de moderación. Es bien sabido que no representan la tendencia reformista del Gobierno de Fernando VII, sino todo lo contrario, el ala más radical del mismo, la dirigida por Calomarde, cuyos límites ideológicos con los apostólicos son bastante tenues. Jorge Urrutia, para hacer compatible la «tendencia liberal» que supone en Larra con su militancia, tiene que suponer también que «el cuerpo había perdido parte de su radicalismo» y que enrolarse en él "es una forma de oponerse al carlismo» (loc. cit.). Tampoco se puede decir, como hace Juan Cano Ballesta, siguiendo a Urrutia y a Varela, que los Voluntarios Realistas se convirtie-

11 Véase Vicente Lloréns, Liberales y románticos, México, El Colegio de México, 1954, pp. 306 y 312-313.

12 Foreign Review, núm. 5, III, 1829, p. 267. Véase J. L. Varela, p. 31, n. 36. 
ron «en los defensores de una monarquía moderada» ${ }^{13}$. Según Miguel Artola, «en líneas generales, el cuerpo de voluntarios realistas [...] mantuvo su fervoroso absolutismo hasta más allá de la vida de Fernando VII, procediendo de sus filas muchos de los que se lanzaron al campo para defender la causa carlista. Todos los testimonios documentales, cualquiera que sea su procedencia, incluidos los de eclesiásticos, empleados o policías, coinciden en calificarlos como el sector más radical del absolutismo» ${ }^{14}$. No parece muy lógico que alguien que se sintiera identificado con los que el mismo historiador considera la «fracción moderada del absolutismo» expresara su celo político alistándose a un cuerpo paramilitar de tal naturaleza y que con ello pretendiera oponerse a los ultraabsolutistas. Si los insistentes deseos expresados por Larra de ser aceptado entre los defensores del Altar y el Trono tuvieran otro móvil que no fuera el de asegurarse un empleo del Gobierno para poder subsistir y hubiera que asignar a los hechos una interpretación política, no sería ésta la del moderantismo; tendríamos que cometer el «escandaloso yerro» de atribuir a Larra el fervoroso absolutismo característico del espíritu del cuerpo, espíritu que se confirma con el nuevo reglamento decretado el 8 de junio de 1826 , cuatro meses antes de que Larra solicitara el ingreso por primera vez.

Según se desprende del estudio de Juan Sisinio Pérez Garzón «Absolutismo y clases sociales: Los Voluntarios Realistas (1823-1833)» ${ }^{15}$, este reglamento, bajo cuyas normas iba a ingresar Larra, fue obra de la

13 «Mariano José de Larra: El hombre y su obra», estudio preliminar a M. J. de Larra, Artículos sociales, políticos y de crítica literaria, Madrid, Alhambra, 1982, p. 6. J. Urrutia se refiere a un documento aportado por M. Artola en La España de Fernando VII, p. 886, una Proclama de o a los voluntarios realistas, de muy difícil filiación: «Si es un escrito dirigido a los voluntarios realistas - dice Artolacomo parece deducirse del texto, en lugar de proceder de ellos, ¿no sería lo más lógico suponer que procede de los moderados, cuyo programa definiría, y trata de ganarse a los tenidos, en la opinión común, como los más acérrimos defensores del absolutismo?» (loc. cit.). Nada indica que lo consiguieran. F. Suárez Verdaguer ha publicado la proclama en Documentos del reinado de Fernando VII, VIII. Los Agraviados de Cataluña, III, pp. 100-102. Según este editor, sería una proclama «dirigida a los voluntarios realistas no sublevados por uno de los jefes de la sublevación», p. 100, nota. De todas formas, no es una señal de que los compañeros de armas de Larra fueran menos radicales que antes. Como se desprende de los documentos publicados por F. Suárez, los Voluntarios Realistas catalanes participaron en la rebelión.

14 Antiguo régimen y revolución liberal, Barcelona, Ariel, 1978, p. 259. Los Voluntarios Realistas de Madrid se sublevaron el 27 de octubre de 1833. Suponemos que Larra ya no pertenecía al cuerpo en esas fechas.

15 Anuario del Instituto de Estudios Madrileños, XV, 1978, pp. 295-310. Véase también del mismo autor, Milicia nacional y revolución burguesa, Madrid, C. S. I. C., 1978, pp. 342-363. 
tendencia radical del Gobierno en una coyuntura de reafirmación absolutista; coyuntura condicionada por lo sucedido en Portugal, donde acaba de implantarse el constitucionalismo. «La inesperada implantación del sistema liberal en Lusitania -escribe M. Artola- provocó grandes inquietudes en la corte española, e introdujo, en cualquier caso, un elemento perturbador en la evolución política que se estaba estudiando. De una parte aumentó el temor de Fernando a caer nuevamente en manos de los negros, situación explotada tanto por los que le aconsejaban liberalizar el régimen como por los que le inducían a un renovado rigor que desarticulase cualquier intento revolucionario ${ }^{16}$. Es evidente que no eran los Voluntarios los que en esta coyuntura aconsejaban medidas liberalizadoras, ni, por lo tanto, apoyaban lo que J. L. Varela considera «una incipiente apertura de la Corona a los movimientos liberales» (p. 144): entre estas medidas, en lo que se ha llamado «conspiración de los moderados», constaba la supresión de los Voluntarios ${ }^{17}$. Como es sabido, frente a la tendencia moderada, en 1826 se impuso el bando apostólico y el abandono definitivo de todo proyecto aperturista.

El reglamento de 1826 obedece a un estado de opinión entre los absolutistas más radicales que se expresa en las informaciones promovidas en 1825 por el Gobierno presidido por el Duque del Infantado ${ }^{18}$, así como en el panfleto Reflexiones apologéticas y reglamentarias sobre las Milicias Realistas, y sobre su utilidad, necesidad y modo de fomentarlas $^{19}$. Una de sus aspiraciones era conseguir la autonomía de la organización paramilitar, independizándola de las autoridades del ejército regular, vistas con recelo por los restauradores del absolutismo. Con el nuevo reglamento se obtiene dicha independencia por medio de un mando único establecido en la Inspección general en cuya oficina iba a trabajar Larra.

Otros aspectos fundamentales, según Pérez Garzón, añade el reglamento de 1826 al primitivo de 1824 . Por ejemplo, el reclutamiento

16 La España de Fernando VII, p. 879.

17 Ibid., p. 949, n. 61.

18 Documentos del reinado de Fernando VII, II. Informes sobre el estado de España (1825), ed. por F. Suárez Verdaguer, Universidad de Navarra, 1966. En estos informes, los obispos consultados se muestran fervientes defensores de los Voluntarios Realistas y solicitan su fomento. A estos deseos de la opinión absolutista más definida responden el nuevo reglamento de 1826 y el consiguiente reclutamiento de 1827.

19 Citado por F. Suárez Verdaguer, «Los cuerpos de Voluntarios Realistas», Anales de la Historia del Derecho Español, XXVI, 1956, pp. 47-88. 
entre las clases desposeídas, como «instrumentalización por parte del absolutismo del malestar antiburgués» ${ }^{20}$ de dichas clases. En este sentido es significativo que Larra ingrese «entre cuatro jornaleros, dos zapateros, un tejedor, un sastre, un pintor, un músico y un escribiente», según nos informa J. L. Varela (p. 239). Otra de las novedades del nuevo reglamento está orientada al reclutamiento de covachuelistas: «se privilegia al realista para obtener destinos —dice Pérez Garzón-, así como para ascensos» ${ }^{21}$. Eso explica, naturalmente, el aumento extraordinario en el número de voluntarios reclutados en 1827 , entre los que se encuentra Larra, en comparación con los dos años anteriores y con los años siguientes hasta la extinción en 1833, según se desprende del cuadro estadístico confeccionado por Pérez Garzón ${ }^{22}$. Si tenemos en cuenta que en 1825 ingresaron en Madrid 221 voluntarios, 134 en 1826, para aumentar de repente a 565 en 1827, y descender en seguida a 203 en 1828, 127 en 1829, 206 en 1830, etc., hasta llegar a sólo 36 en 1833, habrá que pensar que tras la publicación del nuevo reglamento hubo, en el año en que ingresó Larra, una campaña de reclutamiento que resultó en el inusitado incremento, muy por encima del trescientos por ciento, con respecto al año anterior. No cabe pensar, desde luego, que esta campaña estuviera destinada a reforzar las tendencias moderadas que pudiera haber dentro del abolutismo, ni tampoco que con los Voluntarios se quisiera reaccionar contra el levantamiento de los malcontents catalanes. Precisamente algunos de sus cabecillas mencionan al Inspector general de los Voluntarios, entre otros absolutistas madrileños, como supuesta garantía de la sublevación ${ }^{23}$.

El reclutamiento de 1827 responde a las directrices trazadas en el reglamento del año anterior. En efecto, del desglose de las cifras totales resulta que de los 565 nuevos voluntarios del año 27, $124(21,9 \%)$ eran asalariados, $146(25,8 \%)$ artesanos y $184(32,5 \%)$ empleados, mientras que en 1825 sólo hubo $26(11,7 \%)$ empleados, $15(11,2 \%)$ en 1826,10 $(4,9 \%)$ en $1828,11(8,6 \%)$ en 1829 . Ante estas cifras y lo que indica sobre los empleados el nuevo reglamento cabe pensar que no fue el celo

20 «Absolutismo y clases sociales...», p. 309.

21 Ibid., p. 307.

22 Las cifras de Pérez Garzón proceden de los Cuadernos de Voluntarios realistas aprobados por el Ayuntamiento y publicados en los «Diarios de Avisos» de esta capital, que se hallan en el Archivo de la Villa de Madrid. Secretaría. El cuadro estadístico elaborado por el autor se puede consultar en sus dos publicaciones citadas en la nota 16.

23 Véanse las proclamas de Bosch y Ballester, de N. Abrés, en Documentos del reinado de Fernando VII citados, Los Agraviados..., III, pp. 81-83 y 93-95. 
político de servir al Rey, y menos la identificación ideológica, lo que motivó la insistencia de Larra en solicitar el enrolamiento, sino más bien el deseo de aprovecharse de una situación privilegiada para conseguir el empleo y asegurarse un sueldo que aliviara su precaria situación económica en ese vivir de milagro de que habla en su carta de 1835. En las circunstancias indicadas por las cifras, es lógico que para asegurarse el destino a que aspiraba con la influencia de ciertos amigos de su padre, precisamente en la Inspección de Voluntarios, se sintiera obligado a pedir el ingreso en el cuerpo. No sólo «la simultaneidad de ambas ocupaciones era posible», como dice Varela (p. 241), sino que, desde luego, sería de hecho necesaria. Y no sólo «cabe pensar que este destino hace válida su solicitud» (p. 240), sino más bien podríamos decir que, al revés, la solicitud convalida el destino.

¿Cómo es posible que un realista convencido escribiera poco después de su alistamiento los siguientes versos como conclusión de una oda a la libertad inspirada por la intervención europea en Grecia? ${ }^{24}$ :

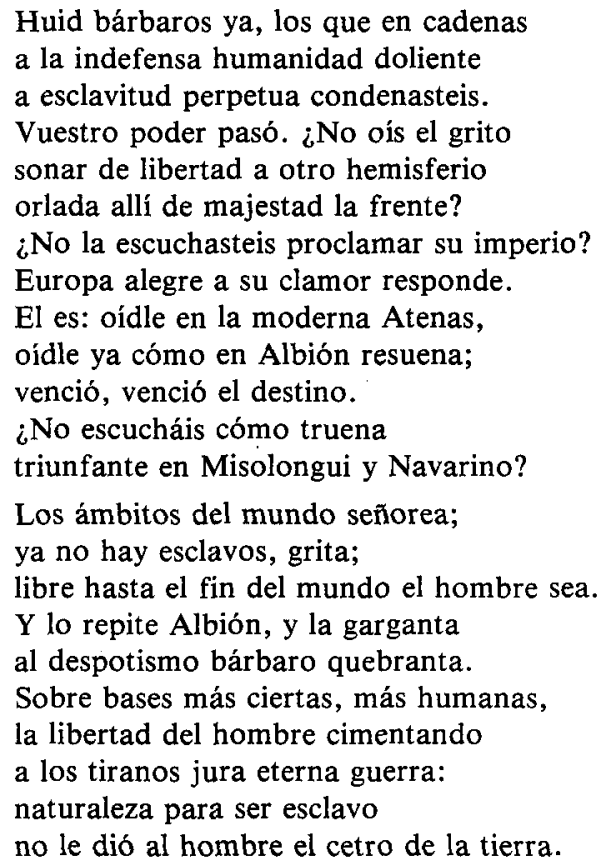

No reproducimos, naturalmente, estos versos como prueba de la inspiración poética del joven voluntario realista que era Larra en 1827.

24 A. Rumeau publicó esta oda, según el manuscrito original de Larra, en «Larra, poète. Fragments inédits. Esquisse d'un répertoire chronologique», BHi, L, 1948, pp. 516-518. 
Sólo lo hacemos para preguntar cómo puede ser que un defensor del Gobierno que interviene militarmente en Portugal en apoyo del absolutismo exaltara la libertad cuyo grito suena con la independencia de América y resuena en Europa: en Inglaterra - refugio de los liberales españoles- que acude con sus tropas no sólo en ayuda de la libertad en Grecia, sino también en el país vecino. Sería un caso insólito de esquizofrenia ideológica ver a un defensor de Fernando VII entusiasmarse contemplando cómo la libertad proclama su imperio en el continente americano y cómo, en Europa, Albión, quebrantando el bárbaro despotismo, repite el grito de la libertad y jura eterna guerra a los tiranos, cimentando así la libertad del hombre. ¿Son estos versos propios de la inspiración ideológica de un realista moderado? Sin duda van más allá de todo conservadurismo realista y fernandino. Claro está que no los publicó. Lo que imprimió fue aquella Oda a la exposición primera de las artes españolas, cuya interpretación ideológica ya expuse en mi libro citado, situándola, como reconoce Jorge Urrutia - según él, acertadamente-, dentro de la expansión burguesa que se asienta ideológicamente en el liberalismo.

La verdad es que el muchacho no se compromete activamente con la oposición. No va a hacer como sus compañeros que montaron el tinglado de los Numantinos ${ }^{25}$. El, en cambio, trabaja en una oficina del Gobierno y elogia las iniciativas de los absolutistas moderados que se vinculan con los intereses económicos y de clase del liberalismo burgués. Larra podía subscribir el estímulo al trabajo y a la industria, el fomento de los «estudios útiles» que, como los reformistas dieciochescos, preconizaban estos moderados en su periódico la Gaceta de Bayona. La idea central de su Oda a la exposición coincide con lo que expone Alberto Lista en el «Prospecto» de dicho periódico: «Una sabia administración que remueve los obstáculos y abre los caminos de la industria, la paz interior que la fomenta, la ilustración que ilustra y dirige, son la curación radical de esta dolencia inveterada, que ya no se puede, como hasta aquí, atenuar con paliativos.» Pero la exaltación de la libertad política expresada en su oda inédita habría encontrado la reprobación del ilustrado gacetero de Bayona de la misma manera que reprobó por aquellas fechas, en una carta al cubano Domingo del Monte, la influencia de Cienfuegos en las poesías de José María de Heredia: «Si he sido demasiado severo - le escribe Lista a su corresponsal-, atribúyalo usted [...] más que todo al deseo de destruir el pésimo efecto que las poe-

25 V. R. Navas Ruiz, "Trayectoria política de Larra», en Imágenes liberales, Salamanca, Almar, 1979, p. 44. 
sías de Cienfuegos han hecho en todas las almas ardientes tanto en materias políticas como literarias. Una exaltación siempre permanente, quiere violar a un mismo tiempo las reglas del mundo social y las del Parnaso. Ya es ocasión de poner freno saludable a esta licencia, que deslumbra los corazones incautos con el nombre de libertad ${ }^{26}$.

Creo que Juan Cano Ballesta formula muy bien esta circunstancia biográfica del joven escritor cuando dice: «Larra demuestra una gran capacidad de ajuste a unas circunstancias difíciles cuando publica, a primeros de octubre de 1827, su Oda a la exposición... Mientras elogiaba el avance industrial, algo muy de acuerdo con sus ideas progresistas, se atraía el favor de ciertos círculos tímidamente renovadores en torno al ministro de Hacienda, López Ballesteros, que le podían ayudar a sacar su proyectado periódico» ${ }^{27}$. Aunque este autor acepta la nueva interpretación sobre los orígenes moderados de Larra, sin embargo no puede menos de percibir una actitud rebelde en el joven escritor: «En la España oscurantista de Fernando VII el joven Larra debió, no obstante, de experimentar sentimientos de rebeldía ante la represión política y carencia de libertades $\gg{ }^{28}$. La inquietante mordacidad de El Duende, a que se refiere Carlos Seco Serrano ${ }^{29}$, nos revela un Larra inconformista con respecto a la realidad social en que vive. Naturalmente, no trata de política, pero como dice el mismo historiador refiriéndose a los dos primeros periódicos de Larra, en 1832 «resulta tan difícil como en 1828 hacer una crítica social que, fatalmente, acaba por apuntar a los fundamentos políticos que hay detrás de todas las formas sociales» ${ }^{30}$. La expresión podrá ser todo lo moderada que se quiera, pero ya sabemos por su oda inédita que su ideal político aspira a la libertad representada por la revolución americana y el sistema liberal inglés. En el opresivo ambiente español en que Larra empieza su carrera no puede menos de parecerle, sin duda, un ideal utópico, por lo que tendrá que dar por buenas las tímidas iniciativas moderadas y conformarse con la realidad. Este es todo su moderantismo.

Las dos citas de Lista proceden de Hans Juretschke, Vida, obra y pensamiento de Alberto Lista, Madrid, C. S. I. C., 1951, pp. 134-135 y 574, respectivamente. Estudio preliminar citado, p. 8.

Ibid., p. 7.

«Asusta pensar que es un Larra de diecinueve años el que rezuma mordacidad en las páginas de El Duende. Desde luego, el panorama que tiene ante sí justifica su actitud: dificultades en su propia situación material, de una parte; horizonte de sombras en el porvenir nacional, de otra.» En «La crisis española del siglo XIX en la obra de Larra», estudio preliminar a la ed. cit. de las Obras de Larra, p. IX. Ibíd., p. XVI.

31 En Obras poéticas, París, Impr. J. Claye, 1866, p. 515. 
Los testimonios retrospectivos de los que vivieron en esta época nos presentan la juventud del día imbuida de espíritu liberal. Ventura de la Vega, desde una perspectiva ya abiertamente conservadora, recuerda el fin de la sublevación de los agraviados: «El partido liberal miró este triunfo como suyo; y ya nos figurábamos tener conquistado al. Monarca, y divisar un horizonte de color de rosa» ${ }^{31}$. Pronto se les iba a quitar el entusiasmo. El horizonte de Larra era sombrío.

Según el testimonio de Mesonero Romanos, el hecho de que el Gobierno les cerrara a los jóvenes las puertas del saber no quitaba que «por todas partes penetrase, a despecho de los gobernantes, el ambiente liberal que se respiraba en la atmósfera» ${ }^{32}$. Era una juventud que, según El Curioso Parlante, «leía con avidez, por espíritu de oposición o resistencia» autores prohibidos como Voltaire, Diderot, Depuis, Volney, Pigault-Lebrun, etc. ${ }^{33}$. También, como el aspirante a literato en el artículo «Don Cándido Buenafé o el camino de la gloria» ${ }^{34}$, leerían $E l$ compadre Mateo, de Henri-Joseph Dulaurens, obra cuya prohibición, como las de otras de los autores citados por Mesonero, proponía Gómez Hermosilla, uno de aquellos realistas moderados ${ }^{35}$. Son testimonio de una corriente heterodoxa que, sobre todo a partir del Trienio, significa, según Alberto Gil Novales, «un esfuerzo minoritario, pero tangible, para abrir España a toda la Ilustración europea, incluso a aquellos valores negadores de las tradiciones religiosa y política». Es una corriente que, como dice este autor, «existió y tuvo tanta importancia que sin ella no es posible entender una figura literaria de la importancia de Larra, o de Espronceda» ${ }^{36}$.

Larra, según creo haber mostrado en trabajos anteriores, se sitúa desde sus orígenes en una tradición ideológica procedente de la tímida Ilustración española; tradición reformista, pero con aspectos francamente heterodoxos, que evoluciona, en contraste con el conservadurismo de los realistas moderados, estancados en el despotismo ilustrado, en una actitud francamente liberal. No voy a repetir aquí lo que dije

32 «Memorias de un setentón», en Obras, ed. de Carlos Seco Serrano, Madrid, B. A. E., 1967, V, p. 159. Ibid., p. 172.

Obras de Larra, ed. cit., I, p. 203.

35 Según Alberto Gil Novales, «Notas en torno a lecturas de Larra», comunicación presentada en un coloquio sobre Larra en la Universidad de Besançon, de próxima publicación. Véase también del mismo autor, El trienio liberal, Madrid, Siglo XXI, 1980, p. 72.

«Notas en torno a lecturas de Larra». 
hace ya años, por ejemplo que El Duende y El Probrecito Hablador aparecen como continuadores, en circunstancias históricas diferentes, de la prensa satírica y reformista de la España ilustrada; lo que a mí me parece que es la justa interpretación ideológica del primer rechazo de Larra, en El Duende, del romanticismo, considerado como una vuelta atrás en relación con las recientes conquistas de la literatura ilustrada: «y ahora que empezábamos a arreglarnos volvamos a desandar otra vez lo andado», se lamenta El Duende Satírico ${ }^{37}$, expresando la misma opinión que había enfrentado a José Joaquín y a Antonio Alcalá Galiano con el reaccionarismo restaurador de N. Böhl de Faber: "Queriendo hacernos volver atrás en el camino de la perfección literaria a la que la España como toda Europa propende - le replican-, nos propone un inadmisible retroceso ${ }^{38}$.

Tenemos que insistir, sin embargo, sobre la presencia indudable en El Duende Satírico del Día de una de las muestras más significativas de esos aspectos heterodoxos de la tradición ilustrada a que antes aludíamos: el panfleto subversivo Pan y toros, atribuido maliciosamente a Jovellanos ${ }^{39}$. Como es sabido, una cita de este panfleto sirve de colofón al artículo de El Duende «Corridas de toros» sobre un tema polémico típico del reformismo social de la Ilustración dieciochesca. Como ya dijo F. C. Tarr en 1928, Larra «parece aquí más cercano al siglo XVIII que en cualquier otro momento del periódico, tanto en lo referente a su erudición como en su pasión por la reforma social. Es significativo que al final del artículo resuma su propia opinión con una cita de Pan y toros, de Jovellanos ${ }^{40}$. Pero lo realmente significativo no es el nombre del autor, sino el panfleto de donde la cita procede. Efectivamente, no tiene la mayor importancia el que Larra creyera o no que el autor era Jovellanos. En el artículo muestra que conocía las opiniones de los ilustrados sobre el tema polémico de los toros, incluida la de Cadalso expresada en sus Cartas marruecas, como indica con acierto J. L. Varela (p. 228). También conocía la auténtica de Jovellanos en su Memoria sobre los espectáculos y diversiones públicas, pero al querer resumir su propia opinión con la autoridad de un texto dieciochesco, lo hace nada

37 Obras, I, p. 18. Véase J. Escobar, Los orígenes..., pp. 166-170.

38 Apud C. Pitollet, La querelle caldéronienne de Johan Nikolas Böhl von Faber et José Joaquín Mora, París, F. Alcan, 1909, p. 126.

39 Véase J. Escobar, «Corridas de toros: polémica taurina, reformismo y sátira política», en Los origenes..., pp. 172-199.

40 «Larra: El Duende Satírico del Día», en la antología de artículos sobre Larra editada por Rubén Benítez, Mariano José de Larra, Madrid, Taurus, 1979, p. 153. Modifico ligeramente la traducción. El artículo apareció originalmente en inglés en $M P h$, XXVI, 1928-1929, pp. 31-46. 
menos que con una cita de Pan y toros, con lo que, en la conclusión del artículo, aflora una escritura reprimida. Naturalmente que al callar el título, el fragmento citado queda extraído de su contexto, pero es la labor del lector competente restituirlo a dicho contexto. Ello configura el papel del destinatario dentro del texto ${ }^{41}$.

No se puede pensar que Larra fuera tan ingenuo que no supiera lo que estaba haciendo, es decir, contaminar inevitablemente la Ilustración moderada de la sátira antitaurina - avalada con la autoridad de Jovellanos y toda la escritura anterior - con la subversión ideológica del panfleto citado. El pasaje aducido sirve de puente entre el artículo «Corridas de toros» y el panfleto Pan y toros y por medio de él lo vincula con la prensa clandestina de finales del siglo XVIII.

Claro que si se concluye desde el punto de vista biográfico que en 1828 Larra era un partidario del régimen, toda la mordacidad de su sátira queda reducida a las innegables convenciones del género y la crítica de los usos y costumbres deja de apuntar a los fundamentos del sistema social y a su organización política: «A la agresividad satírica de sus comienzos - cree J. L. Varela- corresponde en lo ideológico o poético una noción de mesura, bajo la que no es difícil adivinar la enseñanza humanística de las Escuelas Pías y de los Jesuítas, por un lado, y el vigilante patrocinio, por otro, de sus mecenas» (p. 120). Queda así cortada de raíz cualquier ligazón o referencia a otras ideologías no tan mesuradas que puedan emerger en el texto, ya que éste es de 1828, es decir, definido biográficamente como realista moderado.

Pero incluso si aceptáramos que Larra, por su biografía, era un realista convencido, el texto del artículo «Corrida de toros» contradeciría a su propio autor. Por un obvio proceso de significación intertextual, el fragmento citado alude al texto, a la «fuente», en su totalidad, y evoca la ideología que el panfleto representa ${ }^{42}$. En otras palabras, la cita aducida en el artículo remite metonímicamente, lo quiera el autor o no, a todo el texto de donde procede, como también a la totalidad del texto donde se injerta, precisamente como conclusión. En el artículo de Larra concurren, como paratexto, tres formas de escritura taurina propias del siglo XVIII. El texto de Larra contradice paródicamente la es-

41 Véase Gerald Prince, «Introduction à l'etude du narrataire», Poétique, 4, 1973, pp. 178-196.

42 No voy a repetir aquí los títulos clásicos sobre el concepto de intertextualidad, de sobra conocidos; en esta ocasión me refiero sobre todo al esclarecedor artículo de Gustavo Pérez Firmat, «Apuntes para un modelo de la intertextualidad en literatura», $R R$, LXIX, 1978, pp. 1-14.' 
critura que defiende las corridas (Nicolás Fernández de Moratín), identificándose con el reformismo social de la crítica antitaurina (Jovellanos, Cadalso, Clavijo y Fajardo, etc.), a la vez que la traspasa ideológicamente mediante la referencia a Pan y toros, donde la corrida pasa a ser una metáfora de las instituciones del antiguo régimen, de la tiranía civil y religiosa. No se trata de que el artículo de El Duende tenga un carácter subversivo o criptosedicioso, pero cualquier lector que reconociera la supuesta cita de Jovellanos tenía que pensar que se le veía el plumero.

¿Y el elogio áulico? Después de todo lo dicho, no creo que haya que señalar mucho sobre el asunto. Basta remitir al artículo de Tarr sobre El Pobrecito Hablador y a lo que yo ya dije en otras ocasiones ${ }^{43}$. Si Larra estuvo dispuesto a ser Voluntario Realista, no tiene nada de extraño que lo estuviera a alabar al Rey y a su Gobierno, e incluso a aceptar la necesidad de la censura, ya que reconoce la razón de este vigilante organismo del Gobierno en suprimirle un terceto de la «Sátira contra los malos versos de circunstancias», aparecida, con el encadenamiento cortado, en el número quinto de la revista, por lo que advierte que «habiendo sido suprimido por la censura, en verdad con razón, un terceto [...] se olvidó al corregir [las pruebas] en la imprenta indicar con unos puntos aquella pequeña laguna, precaución que se tomará en cualquier otro caso semejante» ${ }^{44}$. ¿Quiere decir que la razón de la censura está en suprimir una idea cuya expresión el ilustrado Gobierno no podía tolerar? Si Larra elogia la ilustración del Gobierno, ¿por qué iba a parecerle mal la represión de los excesos? En la misma sátira inserta una serie de alabanzas que presenta como prueba - ¿por qué tenía que probarlo? - de sus buenas intenciones: «Mucho nos dejamos por decir en esta materia... - dice en una nota a pie de página-. Basta esta corta muestra para que nunca se nos pueda atribuir una mala intención que no tenemos, y para que se vea hasta qué punto llevamos el rigor de la verdad $\gg{ }^{45}$. Es una nota puesta al final de una sarta de encomios a las mejo-

43 F. C. Tarr, «El Pobrecito Hablador: estudio preliminar», RHi, LXXXI, 1933, pp. 428-429. J. Escobar, «El Pobrecito Hablador...», pp. 36-42.

44 Apud C. F. Tarr, «El Pobrecito Hablador...», p. 431. En 1835, escribe Larra que su Pobrecito Hablador era un folleto «mitad mío, mitad del Gobierno; entonces el Gobierno escribía por medio de sus censores la mitad de las obras que veían la luz; un folleto de dos ingenios, si se puede llamar ingenio a la censura, si es que ésta puede tener algo de común con aquél». Obras, IV, p. 336.

45 El subrayado es mío. Obras, I, p. 97. No fue Larra el único liberal bajo cuya firma aparecieron elogios al régimen de Fernando VII. Fermín Caballero, como es bien sabido, director del Eco del Comercio, periódico de los liberales exaltados, tuvo que defenderse de los elogios expresados, en 1832, en su continuación del compendio de Historia Universal de Anquétil. Véase La Abeja, núm. 148, 26 de agosto de 1834. 
ras llevadas a cabo recientemente en el país: Conservatorio de Artes, Museo de Pinturas, Museo de Escultura, Conservatorio de Música, teatro de la plaza de Oriente, edición de las obras de Moratín, Códigos de Comercio y Criminal, Dirección de Minas, reedificación de pueblos arruinados por los terremotos, restablecimiento del crédito y, por último, «la derogación de pena de horca», derogación exaltada con estos versos dirigidos a Fernando VII:

\section{Para siempre aniquilas el suplicio que holló la noble dignidad del hombre.}

Se trata del decreto de 18 de abril de 1832 en el que, para celebrar el cumpleaños de la Reina, se sustituye la horca por el garrote vil, suplicio mucho más humanitario que salvó la dignidad de Mariana Pineda y habría salvado la dignidad de Juan de la Torre y del librero Miyar, recientemente ajusticiados.

Naturalmente, si aceptamos que el autor de El Pobrecito Hablador era un realista moderado y, por lo tanto, defensor del régimen absolutista, tendremos que reconocer sinceras y sin reticencias las alabanzas a Fernando VII y a su Gobierno. No podremos admitir entonces la opinión de C. F. Tarr sobre El Pobrecito Hablador cuando dice que en esta revista «Larra consigue con grandísima habilidad convertir su difícil papel de escritor satírico bajo un régimen absolutista en un arma tanto defensiva como ofensiva. Todo depende de una cosa: de que el enemigo declarado sea el público, la sociedad, y no el gobierno. A éste se le menciona sólo para elogiarlo [...] Esto es "herir a mansalva", desafiar al poder en el mismo gesto con que se le elogia»" ${ }^{46}$. Igualmente habrá que considerar equivocado el criterio más reciente de Carlos Seco Serrano, para quien esta serie de artículos «viene a constituir, en realidad, como el acta acusatoria contra la situación social y el sistema político que [el régimen fernandino] representa ${ }^{47}$. Tampoco podremos aceptar la pretensión del propio Larra cuando más tarde quiere que se vea en esta revista de costumbres la mayor rebelión posible contra el poder, atendidas las circunstancias del momento: «Cuando empecé la difícil carrera de escritor público, empecé con artículos de costumbres. Era a la sazón ministro [Calomarde] y todo el mundo sabe en qué términos y hasta dónde le era entonces lícito, posible al escritor rebelarse contra el poder, aludir a la injusticia. A poder de reticencias, haciendo concesiones, podía uno alguna vez ser atrevido; siempre que pude fuí más que

46 «El Pobrecito Hablador...», p. 248.

47 Estudio preliminar citado a Larra, Obras, I, p. XVI. 
atrevido, fuí temerario... ${ }^{48}$. Al contrario, tendremos que admitir que Larra consideraba que la censura, durante el régimen absolutista, actuaba «en verdad con razón». ¿Quién lo iba a decir?, Larra alabando la censura.

Lo importante, a mi modo de ver, no consiste en que Larra personalmente fuera atrevido o temerario. Si fue Voluntario Realista y consiguió el apoyo de gente del régimen para sacar sus periódicos es que supo adaptarse a las circunstancias. Luego, un actor resentido de sus críticas pudo decir que empezó a escribir «allá en tiempos en que era él uno de los pocos que tenía privilegio y carta blanca para embadurnar de negro los productos de Alcoy y Capellades" ${ }^{49}$. Otro de los pocos fue Fermín Caballero con sus incontables folletos, lo que le valió la acusación no de moderado, sino de calomardino ${ }^{50}$. Lo que importa es que los textos de El Duende y de El Pobrecito Hablador, independientemente de lo que su propio autor dijera después, están escritos de manera que puedan leerse con las reticencias que él reclama en 1835. Así los han leído tantos lectores, como los críticos citados y otros muchos.

No me parece difícil leer en estas revistas con que Larra inicia su carrera de escritor, el anuncio del crítico liberal que viene después. A ellas llega la corriente periodística e ideológica que iniciada en la Ilustración se expande en el Trienio. En momentos de represión, tímida o temerariamente, por medio de reticencias, trata de aflorar de nuevo en los primeros artículos de Larra.

Obras, IV, p. 336.

Véase J. Escobar, «Un episodio biográfico de Larra, crítico teatral, en la temporada de 1834», NRFH, XXV, 1976, p. 65.

Los moderados de La Abeja pretenden que Fermín Caballero, con sus ataques al diccionario de Miñano, le estaba haciendo el juego a Calomarde. Véase Eco del Comercio, núm. 618, 8 de enero de 1836. El artículo del $E c o$, defendiendo a Caballero, aprovecha la ocasión para atacar a los realistas moderados: «El estúpido Calomarde y los suyos ni dos años hubieran podido sostener la arbitrariedad sin la ayuda del maquiavelismo josefino». Sus periódicos «sembraron las doctrinas infernales del despotismo, con vislumbres de ilustración». 